\title{
The East Asian Crisis in Kindleberger-Minsky's Framework
}

A crise da Leste Asiático no modelo Kindleberger-Minsky

OMAR F. SAQIB *,**

\begin{abstract}
RESUMO: O artigo analisa a crise do leste asiático de 1997 no âmbito dos cinco estágios de deslocamento, crescimento, excesso de comércio, repulsa e tranquilidade do modelo Kindleberger-Minsky. Além disso, observa que as recentes interpretações da crise, baseadas nas hipóteses de desequilíbrios fundamentais e pânico financeiro, estão de acordo com os estágios do modelo Kindleberger-Minsky.
\end{abstract}

PALAVRAS-CHAVE: Modelo Kindleberger-Minsky; crise cambial; crise asiática de 1997; contágio financeiro.

ABSTRACT: The paper reviews the 1997 East Asian crisis within the framework of the five stages of displacement, boom, overtrading, revulsion, and tranquility of the KindlebergerMinsky model. It further notes that the recent interpretations of the crisis, based on the hypotheses of fundamental imbalances and financial panic, conform to the stages of the Kindleberger-Minsky model.

KEYWORDS: Kindleberger-Minsky model; 1997 Asian currency crisis; financial contagion. JEL Classification: F31; F32.

\section{INTRODUCTION}

The instability in Indonesia, Korea, Malaysia, the Philippines, and Thailand (hereafter EA5) started out with the floating of the Thai baht in mid-1997 which was immediately followed by a spiral of devaluations in the region. These devaluations rocked the conventional wisdom of the so-called first-generation and the second-generation models of currency crisis. ${ }^{1}$ Nevertheless, the present paper notes

\footnotetext{
* Department of Economics, University of Joensuu, Finland. E-mail: omar.farooq@sbp.org.pk.

** Helpful suggestions by an anonymous referee and Selmo Aranovich are greatly acknowledged.

${ }^{1}$ Contrary to the predictions of the first-generation models (following Krugman 1979), in EA5 the fiscal balances were in surplus and international reserve did not pose any alarming reduction prior to the crisis. For the period 1994-1996, the economies of Indonesia, Korea, Malaysia, the
} 
that the Kindleberger-Minsky model of five stages of displacement, boom, overtrading, revulsion, and tranquility of a financial crisis is fairly comprehensive in unfolding the events of EA5 turmoil. Furthermore, recent interpretations based on the hypotheses of fundamental imbalances and financial panic as the root cause of the crisis after a focused examination conform to the stages of the model.

Thus, this review begins with the stylized facts of the EA5 crisis using the Kindleberger-Minsky model (section 2). It then compares the two hypothesis of the causes of the crisis with the main framework of this paper (section 4). Final remarks then follow (section 4).

\section{ANATOMY OF THE CRISIS}

The Kindleberger-Minsky model can be summarized in five different, yet relatively contemporaneous stages of displacement, boom, overtrading, revulsion, and tranquility. ${ }^{2}$

The crisis starts out with a displacement, an exogenous shock, to the macroeconomic system that alters profit opportunities in at least one sector. Individuals, firms, and businesses take advantage of the new opportunities thus paving the way for a "boom". Typically, a boom enlarges the money supply and results in an increase in credit channels. With the propagation of positive feedback, the economy involves in overtrading. Overtrading signifies the exaggeration of some activity, for example, over-borrowing, over-investment, over-consumption. Prices and profits continue to increase until a few insiders decide to sell out after taking their profits. This is the period of revulsion. Economic agents realize that the market cannot go higher. Given even a trivial shock, this realization may tum into a stampede. Consequently, a crisis breaks out and panic feeds on itself. Tranquility sets in when one or more of three things happen: (i) low prices tempt people to move into less liquid assets; (ii) cutting off of trade because of limits on price declines; (iii) a lender-oflast-resort convinces the market of sufficient cash. ${ }^{3}$

The model is quite suggestive in that it provides a systematic interpretation of the recent East Asian crisis. The stages of the model can be traced in five episodes

\footnotetext{
Philippines, and Thailand on average recorded budget surpluses of 1.44, 0.24, 2.95, 0.61, and 2.34 percent,of their respective GDPs. The average gross international reserves of these economies for the same time period were at 7.83, 7.00, 31.40, 11.84, and 21.33 percent of GDP (World Bank 1998). On the other hand, as opposed to the main prediction of the second-generation models (following Obstfeld 1986), high growth rates in EA5 provide little room for concern on the part of governments to abandon the peg in favor of internal objectives. In the period 1994-1996, Indonesia, Korea, Malaysia, the Philippines, and Thailand recorded an average GDP growth rates of 7.76, 8.24, 8.96, 4.95, and 8.14 percent respectively (World Bank 1998).

${ }^{2}$ The model stems from the writings of Hyman Minsky (198 2a, 19826, 1975), championed by Charles Kindleberger in Manias, Panics, and Crashes: A History of Financial Crises (1996, pp. 11-6).

${ }^{3}$ Kindleberger (1996, p. 15).
} 
of the EA5 turmoil: liberalization policies, credit growth, overinvestments, financial distress and crisis, and lender-of-last-resort. ${ }^{4}$

\section{Liberalization Policies - Displacement}

Following the general trend of the previous decade in developing countries, the economies of EA5 also pursued liberal economic policies. Particularly since the mid-1980s, these countries started to open up through trade and financial liberalization. As a result, volumes of foreign capital started to pour into this region. However, the driving force behind these flows was not the financial deregulation alone but also the sound economic performance of these dynamic economies.

Most notably, net foreign portfolio and direct investments account for the surge in these inflows. According to the International Monetary Fund, capital inflows to the east Asian countries during 1990-1994 more than doubled throughout the 1980 s and amounted to 50 percent of capital inflow into the whole developing world (Park 1996, p. 359). It is not surprising, then, that the annual capital inflows into the EA5 averaged over 6 percent of GDP between 1990 and 1996 (Radelet and Sachs 1998b, p. 23).

Since economies of this region are typically characterized by their high saving rates, the capital inflows resulted in massive investments. The boom in investments accompanied credit growth.

\section{Credit Growth - Boom}

A major proportion of capital flow into EA5 changed its composition from 1990-1994 onwards. According to the Bank for International Settlements (1998), at annual rates between 1990-1994 and 1995Q1-1996Q3 net interbank lending, bank lending to non-banks, and bond issuance increased from 19 billion dollars to 75 billion dollars. On the domestic front, bank credit to the private sector in EA5 increased from an average of 28.6 percent of GDP in 1980 to 61.9 percent of GDP in 1995. However, bank credit to the private sector in Indonesia and Thailand experienced more than average increases, whereas Korea and the Philippines were below average, and Malaysia accounted for an average increase (Bank for International Settlements 1997). Radelet and Sachs (1998a) note that in Malaysia, Thailand, and Korea claims in the private sector jumped from about 100 percent of GDP in 1990 to 140 percent in 1996, and in the Philippines credit growth on average was over 40 percent from 1993 to 1996.

The characteristic of high saving rates coupled with the repute of sound economic performance, credible fixed exchange rate regimes, and huge capital inflows

\footnotetext{
${ }^{4}$ In current economic literature, two analyses of the Asian crisis by Palma (1998) and Kregel (1998) are compatible with that of the present review.
} 
gave rise to investments. Some in already profitable industries and some in newly boosted non-tradable sectors such as real estate.

\section{Overinvestment - Overtrading}

Not long ago East Asian economies were praised for their successful track record based on dazzling export-led growth and sound macroeconomic fundamentals. The popularity of the so-called 'Asian Miracle' was iterated everywhere. The data on risk premium, credit ratings and other indicators reported by market participants, analysts, and especially business press and media ranked them high. The skeptics of this repute were rare. Bello (1998) while commenting on the East Asian financial crisis blames the business press and media for creating a false psychology of permanent boom that eventually resulted in the financial turmoil. ${ }^{5}$ ln this regard, he cites an assessment of the Thai economy in December 1996 by a leading expert on Asian investment who was widely quoted in the Economist, Far Eastern Economic Review, Financial Times, Reuters, and the Asian Watt Street Journal (ibid., p. 48): "We believe that current pessimism about the Thai economy is based on a number of key misconceptions. We do not believe any of the following: (i) Thailand is entering a recession; (ii) Investment is collapsing; (iii) Export growth is collapsing; (iv) The Bank of Thailand has lost control; (v) Current account deficit is unsustainable; (vi) Thailand faces a debt crisis; (vii) There is a chance that the baht will devalue".

These features contributed to the conditions of what is known as "market euphoria". This euphoria, in tum, resulted in high levels of investments, may it be for speculation purposes or already heavily invested corporate sector. From the mid-1980s and throughout the 1990s, the economies of East Asia maintained very high investment rates. With the exception of the Philippines, the EA5 recorded an average investment rate of more than 30 percent of their GDP. $\ln 1996$, the investment rates in Indonesia, Korea, Malaysia, the Philippines, and Thailand were 32.1, 36.8, 42.2, 23.2, and 42.2 percent of their respective GDPs (Bank for International Settlements 1998). The investments were destined towards two main sectors: the corporate sector engaged in manufacturing products and speculative investments in land and real estate. The Korean conglomerates are the most notable examples of overinvestment in the corporate sector. The speculative activities in the land and real estate sectors were most evident in Thailand, Malaysia, and the Philippines. Between 1990 and 1993, the stock market for the property sector in Thailand rose by $395 \%$; in Malaysia and the Philippines between 1990 and end of 1996 by $160 \%$ and $271 \%$ respectively (Corsetti et al. 1998).

The euphoria based on many years of virtually uninterrupted growth led near-

\footnotetext{
${ }^{5}$ In a similar yet slightly different context, Kindleberger calls this phenomenon as "venal journalism" (1996, pp. 74-6).
} 
ly everyone to underestimate the rising determinants of a financial crisis. Thus, the adverse consequences of this euphoria though patent even in 1996 were largely neglected.

\section{Financial Distress and the Crisis - Revulsion}

The traditional signals of financial fragility, such as export growth slump, current account deficits, and rising short-term debts started to become evident as early as 1996 . Even then and irrespective of the profitability prospects, the corporate sector borrowed and invested heavily. This contributed to the conditions of oversupply, especially in the semi-conductor industry, which resulted in price collapse. An export growth slump was almost unavoidable. ${ }^{6}$

The return on invested capital in some of the Korean chaebols followed a significant reduction. The return on invested capital during 1992-1996 in Hanbo, Sammi, Jinro, Kia, and Dainong was 3.0\%, 2.9\%, 2.7\%, $18.9 \%$, and $6.8 \%$ respectively; in 1996 alone the returns with the exception of Sammi fell down to $1.7 \%$, $3.2 \%, 1.9 \%, 8.7 \%$, and 5.5\% (Corsetti et al. 1998 ). Consequently, in January 1997, Hanbo collapsed under debts, followed by Sammi, Jinro, and Kia defaulting in March, April, and July.

In early February 1997, the Samprasong Land, a Thai financial company, missed payments on its foreign debt. This precipitated a fall in the property prices and distress for all those financial institutions that had lent heavily to property companies. The impact of these developments was bound to affect other countries of the region. On March 28, 1997, the Malaysian central bank (Bank Negara) restricted loans to property and stocks to avoid a similar situation as in Thailand.

In late June 1997, the Thai central bank abandoned support for 16 cashstrapped finance companies. Thus, igniting foreign fund withdrawals and initiating speculative attacks that eventually forced the Thai baht to float on July 2, 1997. The crisis in Thailand quickly engulfed Malaysia and Indonesia shortly followed by the Philippines. Indonesia had to float its rupiah on the 14th of August, whereas Malaysia and the Philippines had to widen the bands of their respective currencies.

At the beginning of the crisis, the panic on the part of the investment community induced huge withdrawals of foreign capital from the region, thus worsening the crisis. The Korean government defended its won the whole summer and autumn of 1997 but eventually had to float on December 16, 1997. The floating of these currencies was the first major break-down of the much deeper melt-down that followed. To calm down the panic, action of a lender-of-last-resort was expected.

\footnotetext{
${ }^{6}$ Other notable factors: appreciation of the Japanese yen against the US dollar after 1994 and the devaluation of the Chinese yuan in early 1994 (Radelet and Sachs 1998b), reduction in the intra-regional trade in the East Asian region (Bank for International Settlements 1997).
} 


\section{Lender-of-Last-Resort - Tranquility}

In spite of initiating one of the largest bail-outs in the history of financial crises, the action of the International Monetary Fund has come under heavy criticism. It is generally argued that the traditional demand-side conditionalities and financial reform suggestions unnecessarily exacerbated the instability. In particular, prescription of closing down insolvent banks, high interest rates, and fiscal contractions resulted in the deepening of the EA5 turmoil. At a later stage the Fund relaxed many of its requirements and dealt the situation in a relatively unorthodox manner. However, it seems more plausible to accept other reasons, for example transference into less liquid assets due to price declines, for the relative tranquility that returned to the region than the actions of the lnternational Monetary Fund (apart from the fact that the panic cannot go on forever!).

\section{FUNDAMENTAL IMBALANCES OR FINANCIAL PANIC?}

Following the EA5 turmoil, a large number of interpretations on the causes of the crisis have emerged. Two compatible explanations are in the vanguard: that fundamental imbalances triggered the crisis, and that financial panic was at the core of the crisis. A focused examination of these views reveals that they are in accordance with the stages of the Kindleberger-Minsky model.

\section{Fundamental Imbalances}

According to this opinion, at the root of the crisis was the moral hazard problem which spread through the corporate, financial, and international level resulting in fundamental imbalances, such as current account deficits and overvalued real exchange rates, which in turn, amid investor's panic ended in the crash. While explaining the root of the crisis, Corsetti, Pesenti, and Roubini note: "The moral hazard problem in Asia magnified the financial vulnerability of the region during the process of financial markets liberalization in the 1990s, exposing its fragility vis-àvis the macroeconomic and financial shocks that occurred in the period 19951997. The problem exhibited three different, yet strictly interrelated dimensions at the corporate, financial, and international level”. (1998, p. 2)

The essence of this view is the problem of moral hazard causing deterioration of fundamentals. Moral hazard arises, from a lender's point of view: due to asymmetric information and enforcement costs; and from a borrower's point of view: as a borrower does not bear loss in the case of a project failure (Mishkin 1992). However, the Kindleberger-Minsky model suggests that the problem may be exaggerated by "market euphoria". When borrowers and lenders or other economic agents rely heavily on the sound performance of the economy, drawing their opinions based on risk premium data, credit ratings and/or other indicators reported by market participants and analysts. 
The hypotheses is that the so called "Asian Miracle", which was further boosted with huge capital inflows (especially in the form of international bank lending) after the pursuance of liberalization policies, overcame the worries of a borrower and a lender (local or international) in the case of a riskier project. Furthermore, a project cannot be held riskier when either there is an inflation of financial assets (as in the case of Malaysia and Thailand in real estate sector), or investment in corporate sector with relatively profitable past (as in the case of Korean Chaebols). In addition to this, the problem also arises due to explicit or implicit guarantees by a lender-of-last-resort.

The moral hazard problem in the case of East Asia cannot be attributed only to, as generally perceived, corrupt governments, mismanaged banking system, or a Jack of transparency in corporate governance. The market euphoria had a major role in exaggerating the problem. It was not long ago when countries of East Asia were known as miracle economies. Thus, the argument of fundamental imbalances refers to the overtrading stage of the Kindleberger-Minsky model as discussed in the preceding section.

\section{Financial Panic}

The financial panic hypothesis, forwarded by Steven Radelet and Jeffrey Sachs, disregards the deterioration of fundamentals as the root cause of the East Asian financial crisis. The argument advanced is that the fundamental imbalances were sustainable, whereas the vulnerability of large-scale capital inflows to financial panic was not, this being the ultimate cause of the crash.

Following a period of financial distress, a reversal of foreign capital inflows began when the Bank of Thailand withdrew support from cash-strapped finance companies. Financial panic on the part of the investment community triggered capital outflows while the situation was further exacerbated by the mismanagement of the crisis by local governments and wrong policy prescription of international rescue programs. ln other words: “... collapse came... because of a euphoric inflow of capital that could not be sustained... the Asian crisis... caused by a boom of international lending followed by a sudden withdrawal of funds. At the core of the crisis were large-scale foreign capital inflows into financial systems that became vulnerable to panic... A combination of panic on part of the international investment community, policy mistakes at the onset of the crisis by Asian governments, and poorly designed international rescue programs have led to a much deeper fall". (Radelet and Sachs 1998a, p. 2)

The emphasis in this interpretation is on panic. Eventually, market euphoria based on overtrading ends in a crash, usually preceded by or amid panic. Thus, the financial panic hypothesis refers to the revulsion stage of the KindlebergerMinsky model. 


\section{FINAL REMARKS}

In spite of several explanations of this crisis in recent yimes, for some economists it still remains a debatable issue. As Krugman (1999, p. 1) notes, "The truth is that nobody really imagined that something like the Asian financial crisis was possible, and even after the fact there is no consensus about why and how it happened." Nonetheless, the Kindleberger-Minsky model fairly comprehensively unfolds the events of EA5 turmoil. Moreover, it reflects the two leading interpretations of fundamental imbalances and financial panic of the crisis in its two distinctive stages of overtrading and revulsion.

Furthermore, the Kindleberger-Minsky model invites a more focused examination of its stages within the context of EA5 crisis. Several issues are worth detailed investigation. Firstly, an analysis of the liberalization policies in the EA5 region. Secondly, measurement of the credit growth prior to the crisis. Finally, to find the determinants of overinvestments in relation to the role of market participants, analysts, and especially business press and media, apart from the traditional determinants of investments.

\section{REFERENCES}

Bank for international Settlements (1998), 68th Annual Report, Baste, BIS.

Bank for international Settlements (1997), 67th Annual Report, Baste, BIS.

Bello, W. (1998), “Speculations, Spins and Sinking Fortunes “, Development Dialogue, The Journal of the Dag Hammarskjöld Foundation, 1, 42-53.

Corsetti, G., P. Pesenti, and N. Roubini (1998), What Caused the Asian Currency and Financial Crisis? Part 1: A Macroeconomic Overview, NBER Working Paper No. 6833, Massachusetts, National Bureau of Economic Research.

Kindleberger, C. (1996), Manias, Panics, and Crashes: A History of Financial Crises, 3rd Edition, New York, John Willey \& Sons.

Kregel, J. (1998), Yes, “It” Did Happen Again - A Minsky Crisis Happened in Asia, Working Paper No. 234, New York, The Jerome Levy Economics institute.

Krugman, P. (1999), Analytical After thoughts on the Asian Crisis,Mimeo. Massachusetts, MIT. Krugman, P. (1979), “A Model of Balance-o f-Payments Crises”, Journal of Money, Credit, and Banking, $11,311-25$.

Minsky, H. (1982a), Can “It” Happen Again: Essays on Instability and Finance, New York, M. E. Sharpe. Minsky, H. (19826), “The Financial-Instability Hypothesis: Capitalist Processes and the Behavior of the Economy", in C. Kindleberger and J. Laffargue (eds.), Financial Crises: Theory, History, and Policy,New York, Cambridge University Press.

Minsky, H. (1975\} John Maynard Keynes, New York, Columbia University Press.

Mishkin, F. (1992), “Anatomy of a Financial Crisis”, Journal of Evolutionary Economics, 2, 115-30. Obstfeld, M. (1986), "Rational and Self-fulfilling Balance-of-Payments Crises," American Economic Review, 76, 72-81.

Palma, G. (1998), “Three and a Half Cycles of 'Mania, Panic, and [Asymmetric] Crash': East Asia and Latin America Compared", Cambridge Journal of Economics, 22, 789-808.

Park, Y. C. (1996), "East Asian Liberalization, Bubbles, and the Challenge from China”, Brookings Papers on Economic Activity, 2, 357-71.

Radelet, S. and J. Sachs (1998a), The Onset of East Asian Financial Crisis, NBER Working Paper $n^{\circ}$ 
6680, Massachusetts, Nacional Bureau of Economic Research.

Radelet, S. and J. Sachs (1998b), “The East Asian Financial Crisis: Diagnosis, Remedies, Prospects”, Brookings Papers on Economic Activity, 1, 1-90.

World Bank (199 8), World Development Indicators, CD Rom. 